Jurnal Dinamika Sosial Ekonomi Vol.22 No.1, Juni 2021 : 75-87

ISSN 1411-593X (print); ISSN 2721-3137 (online)

\title{
Pemberdayaan Masyarakat Melalui Program Kampung Organik (Studi Kasus Di Kampung Ngemplak Sutan Kelurahan Mojosongo Kecamatan Jebres Kota Surakarta)
}

\section{Community Development Through Organic Vegetable Village Program (Case Study In Ngemplak Sutan Sub Village, Mojosongo Village, Jebres District, Surakarta City)}

\author{
Muhammad Ramajaya*, Daru Retnowati, Teguh Kismantoroadji \\ Program Studi Agribisnis Jurusan Agribisnis Fakultas Pertanian Universitas \\ Pembangunan Nasional "Veteran" Yogyakarta \\ JL. SWK (Lingkar Utara) Condong Catur Yogyakarta Indonesia \\ *Email korespondensi: muhramajaya@gmail.com
}

Diterima tanggal : 14 Mei 2021 ; Disetujui tanggal : 28 Mei 2021

\begin{abstract}
This research aims to (1) examines the application of empowerment principles in the Organic Vegetable Village program.(2) Examine the management of the Organic Vegetable Village Program by the Community Self-help group (KSM) Kahuripan Sejahtera. (3) examines the process of empowering the Ngemplak Sutan village community through the organic vegetable village program. This method used in case in this study was qualitative with a case of study approach. Determination of data sources was done purposively chairman and vice chairman of KSM Kahuripan Sejahtera,member of KSM Kahuripan Sejahtera and the empowerment program companion from Rumah Zakat. The data used in this study are primary data and secondary data. Data collection techniques with observation, interviews, and documentation by testing the validity of data using triangulation. Data analysis technique with collecting data, data reduction, data presentation and withdrawal of conclusion and verification. The result of the study concluded that (1) The empowerment of Organic Vegetable Village Program in Ngemplak Sutan village applies the principles of capacity building, changing community culture, and changing systems (2) the management of Organic Vegetable Village Program by the KSM Kahuripan Sejahtera in Ngemplak Sutan Village is conducted thorugh planning, organizing, actuating, implementation, and controlling. (3) the process of empowering the Organic Vegetable Village Program in Ngemplak Sutan Village has been through the process of awareness, capacitating, making rules / policies, and has gone through the process of empowering
\end{abstract}

Keywords: empowerment principles, empowerment process, management, organic vegetables village

\footnotetext{
ABSTRAK

Penelitian ini bertujuan untuk (1) mengkaji penerapan prinsip pemberdayaan pada Program Kampung Sayur Organik (2) Mengkaji pengelolaan Program Kampung Sayur Organik oleh Kelompok Swadaya Masyarakat (KSM) Kahuripan Sejahtera
} 
(3) Mengkaji proses pemberdayaan masyarakat kampung Ngemplak Sutan melalui Program Kampung Sayur Organik. Penelitian ini merupakan penelitian kualitatif dengan metode pelaksanaan studi kasus dan pengambilan informan secara purposive sampling, yaitu Ketua dan Wakil Ketua KSM Kahuripan Sejahtera, Anggota aktif KSM Kahuripan Sejahtera, dan Pendamping program pemberdayaan Rumah Zakat. Sumber data yang digunakan adalah data primer dan data sekunder.Teknik pengumpulan data menggunakan observasi, wawancara dan dokumentasi. Keabsahan data yang diperoleh akan diuji dengan teknik triangulasi pengumpulan data. Teknik analisis data yaitu dengan mengumpulkan data, mereduksi data, penyajian data, dan penarikan kesimpulan dan verifikasi. Hasil penelitian ini memberikan kesimpulan bahwa (1) Pada pemberdayaan Program Kampung Sayur Organik di Kampung Ngemplak Sutan menerapkan menerapkan prinsip pemberdayaan yaitu prinsip membangun kapasitas, merubah kukltur masyarakat, dan mengubah sistem (2) Pengelolaan Program Kampung Sayur Organik oleh KSM Kahuripan Sejahtera di Kampung Ngemplak Sutan melalui perencanaan, pengorganisasian, pelaksanaan, dan pengawasan. (3) Proses pemberdayaan Program Kampung Sayur Organik di Kampung Ngemplak Sutan melalui proses penyadaran, pengkapasitasan, pembuatan aturan / kebijakan, dan telah melalui proses pemberian daya.

Kata kunci: prinsip pemberdayaan, proses pemberdayaan, pengelolaan, kampung sayur organik

\section{PENDAHULUAN}

Kampung Ngemplak Sutan terletak di Kelurahan Mojosongo Kecamatan Jebres Kota Surakarta. Kondisi di Kampung Ngemplak Sutan kini mulai terasa rindang dan sejuk dipandang mata karena kini telah banyak tanaman baik buahbuahan dan sayuran yang ditanam sepanjang jalan dan gang didepan rumah - rumah warga Kampung Ngemplak Sutan. Selain itu Kampung Ngemplak Sutan terlihat bersih dan rapi jarang ditemukan sampah yang terbuang sembarangan.

Kampung Ngemplak Sutan memiliki warga yang memiliki beragam profesi sebagai pegawai,buruh, serta bertani. Awalnya warga Kampung Ngemplak Sutan hampir tidak ada yang menanam sayuran di halaman rumah serta tidak terfikir terkait pengelolaan lingkungan sama sekali dikarenakan warga belum mengetahui manfaat dari pemanfaatan lahan dengan urban farming dan pengelolaan lingkungan. Pada tahun 2013, berawal dari program-program pemberdayaan masyarakat di wilayah binaan Rumah Zakat Cabang Surakarta yang memberikan program Kampung Sayur Organik ke Kampung Ngemplak Sutan. Tujuan utamanya 
Ramajaya, et.al. Pemberdayaan Masyarakat Melalui Program Kampung Organik

untuk memberdayakan warga agar dapat mandiri pangan di lingkup keluarga serta produktif memanfaatkan lingkungan yang ada.

Program pemberdayaan tersebut juga memberi bantuan kepada warga berupa bantuan materi dan nonmateri seperti bantuan bibit, media tanam, sosialisasi, serta penyuluhan agar meningkatkan minat dan ketertarikan warga dalam mewujudkan program kampung sayur organik tersebut. Selain itu Kampung Ngemplak Sutan mempunyai potensi yang baik untuk bisa dikembangkan menjadi tempat wisata. Hal tersebut didukung dengan adanya lahan pekarangan yang cukup baik, ketersediaan air yang cukup, pupuk yang dihasilkan dari ternak warga, dan yang paling utama kemauan dari sebagian besar warga masyarakat dalam melakukan program Kampung Sayur Organik tersebut.

Adanya program kampung sayur organik di Kampung Ngemplak Sutan telah membuat warga sadar akan manfaat dari urban farming dan juga pengelolaan lingkungan.. Bentuk kesadaran masyarakat tersebut yaitu semakin minat dan tertariknya warga Kampung Ngemplak Sutan untuk mengembangkan kampung sayur organik melalui menanam sayur organik, memelihara unggas, dan memelihara ikan konsumsi di setiap rumah agar mandiri pangan. Program kampung sayur organik juga mendatangkan usaha baru yang menghasilkan nilai ekonomis dari hasil penjualan bibit tanaman yang dibudidayakan. Warga Kampung Ngemplak Sutan kini juga aktif mengelola program Kampung Sayur Organik melalui KSM Kahuripan Sejahtera.

Program kampung sayur organik juga membekali warga akan keterampilan budidaya sayuran organik, berternak, mengolah limbah lingkungan sekitar sehingga dapat menjadikan warga mandiri pangan dan memberi nilai tambah. Berdasarkan latar belakang di atas, penelitian ini bertujuan untuk mengkaji penerapan prinsip pemberdayaan masyarakat pada Program Kampung Sayur Organik di Kampung Ngemplak Sutan, mengkaji pengelolaan Program Kampung Sayur Organik oleh KSM Kahuripan Sejahtera, dan mengkaji proses pemberdayaan masyarakat Kampung Ngemplak Sutan melalui Program Kampung Sayur Organik. 


\section{METODE PENELITIAN}

Lokasi penelitian berada di Kampung Ngemplak Sutan, Kelurahan Mojosongo, Kecamatan Jebres, Kota Surakarta. Penelitian dilakukan pada bulan Februari sampai bulan Oktober 2020. Jenis penelitian yang digunakan adalah penelitian kualitatif. Metode penelitian kualitatif adalah metode penelitian kualitatif adalah metode penelitian yang berlandaskan pada filsafat postpositivisme, digunakan untuk meneliti pada kondisi obyek yang alamiah, (Sugiyono, 2017).

Penelitian ini menggunakan pendekatan studi kasus. Fokus penelitian adalah proses pemberdayaan dan pengelolaan program Kampung Sayur Organik di Kampung Ngemplak Sutan, Kelurahan Mojosongo, Kecamatan Jebres, Kota Surakarta. Teknik penentuan informan dilakukan dengan cara purposive sampling, yaitu dipilih dengan pertimbangan dan tujuan tertentu (Sugiyono, 2017).

Pada penelitian kualitatif subjek penelitian disebut dengan istilah informan, yaitu orang memberi informasi tentang data yang diinginkan peneliti berkaitan dengan penelitian yang sedang dilaksanakan. Adapun informan dalam penelitian ini adalah Bapak Paryanto sebagai Ketua Kelompok Swadaya Masyarakat Kahuripan Sejahtera, Bapak Mulyadi sebagai wakil ketua Kelompok Swadaya Masyarakat Kahuripan Sejahtera, Bapak Hargiyo sebagai anggota aktif Kelompok Swadaya Masyarakat Kahuripan Sejahtera, Bapak Joko Adiyanto sebagai relawan pembina program pemberdayaan Rumah Zakat. Key informan dalam penelitian ini adalah ketua Kelompok Swadaya Masyarakat Kahuripan Sejahtera. Teknik pengumpulan data menggunakan observasi, wawancara, dan dokumentasi. Analisis data dilakukan dengan pengumpulan data, reduksi data, penyajian data dan penarikan kesimpulan.

\section{HASIL DAN PEMBAHASAN}

Penerapan Prinsip Pemberdayaan Masyarakat Pada Program Kampung Sayur Organik

Menurut Sulaeman (2012) prinsip utama pemberdayaan masyarakat adalah membangun dan merubah struktur, sistem, dan kultur masyarakat yang tidak diuntungkan baik oleh struktur kekuasaan, sistem sosial ekonomi dan budaya. Pada 
Ramajaya, et.al. Pemberdayaan Masyarakat Melalui Program Kampung Organik

Program Kampung Sayur Organik yang di tujukan kepada warga Kampung Ngemplak Sutan oleh Rumah Zakat membentuk serta meruba sistem, kultur masyarakat, sosial dan ekonomi warga kea rah yang lebih baik .

Program Kampung Sayur Organik merupakan pemberdayaan yang mengandalkan partisipasi warga dalam prosesnya yang mana warga ikut dalam proses perencanaan, pengorganisasian, pelaksanaan, hingga pengawasan. Dalam ikut berpartisipasi warga tidak menerima paksaan dari pihak manapun, warga diberi kebebasan untuk mengikuti program atau tidak. Untuk dapat ikut serta dalam program Kampung Sayur Organik yang paling dasar yaitu dengan memanfaatkan lahan pekarangan dengan menanam sayuran. Dari program tersebut walaupun tanpa paksaan namun hingga kini terdapat sekitar $60 \%$ warga yang masih aktif menjalankan kegiatan. Hal tersebut sesuai dengan pernyataan Hakim (2017) yang menyatakan bahwa keberhasilan suatu pembangunan pada dasarnya sangat ditentukan oleh partisipasi masyarakat, baik dalam pemberian input, pelaksanaan, pemantauan serta evaluasi dan pemanfaatan hasil-hasil pembangunan.

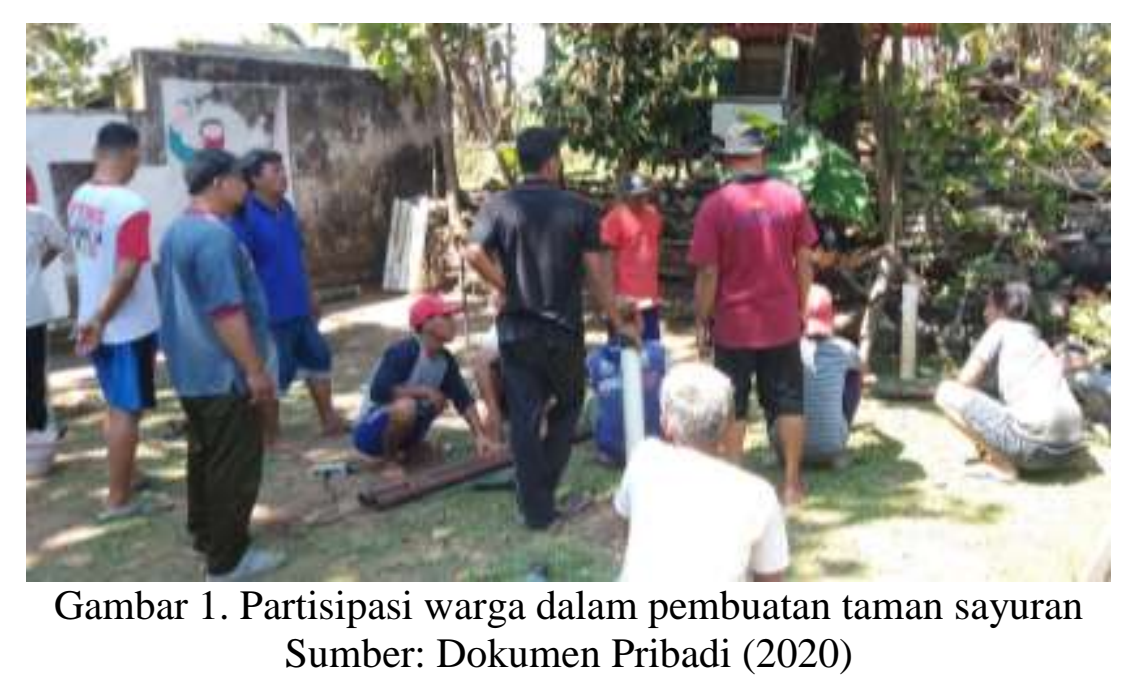

Pada proses pemberdayaan, warga Kampung Ngemplak Sutan ikut berswadaya dalam merintis dan mengembangkan program diantaranya yaitu berswadaya tenaga, pikiran, permodalan dan sarana pendukung program. Warga mendapat bantuan dan dukungan dari pihak luar namun hanya bersifat stimulant sedangkan sisanya lebih banyak mengedepankan sumberdaya pengembangan 
kapasitas dan kemandirian yang sebagian besar berasal dari warga Kampung Ngemplak Sutan sendiri. Karena swadaya dibutuhkan untuk membantu merintis dan mengembangkan program Kampung Sayur Organik sehingga tidak hanya mengandalkan bantuan, terutama permasalahan permodalan. Hingga saat ini program Kampung Sayur Organik masih berjalan di Kampung Ngemplak Sutan masih banyak mayoritas warga yang menjalankan kegiatan program dan berjumlah 27 warga yang aktif dalam keanggotaan KSM Kahuripan Sejahtera yaitu 13\% dari keseluruhan kepala keluarga yang terdaftar di RW 37 berjumlah 197 kepala keluarga Program Kampung Sayur Organik masih berlanjut hingga saat ini dikarenakan mayoritas warga masih menjalankan program dan KSM Kahuripan Sejahtera masih aktif mengelola dengan jumlah 27 anggota terdaftar Hal tersebut sesuai dengan pernyataan Sulaeman (2012) yang menjelaskan salah satu prinsip pemberdayaan yaitu prinsip akibat yang artinya kegiatan pemberdayaan harus memberikan pengaruh yang baik atau bermanfaat

Kegiatan Urban Farming yang merupakan kegiatan utama di Kampung Sayur Organik telah dikembangkan yang awalnya hanya penanaman tanaman sayuran dan buah kini dikembangkan melalui beberapa kegiatan seperti budidaya jamur tiram, ternak unggas petelur, dan aquaponic. Adanya pengembangan kegiatan program merupakan hasil dari partisipasi KSM Kahuripan Sejahteran bersama warga yang bekerja sama saling brkomunikasi dan berdiskusi . sehingga memunculkan gagasan baru. Dampak dari adanya pengembengan adalah berkembangnya Kampung Sayur Organik Hal tersebut sesuai dengan pernyataan Sulaeman (2012) yang menjelaskan salah satu prinsip pemberdayaan yaitu prinsip asosiasi yang artinya setiap kegiatan pemberdayaan masyarakat harus dikaitkan dengan kegiatan lainnya.

\section{Pengelolaan Program Kampung Sayur Organik oleh KSM Kahuripan Sejahtera}

Program Kampung Sayur Organik dikelola oleh Kelompok Swadaya Masyarakat Kahuripan Sejahtera yang merupakan kelompok sekaligus wadah yang bertugas mengelola sekaligus membina warga Kampung Ngemplak Sutan agar mampu berdaya melalui kegiatan Program Kampung Sayur Organik sehingga 
Ramajaya, et.al. Pemberdayaan Masyarakat Melalui Program Kampung Organik

dapat mewujudkan desa berdaya, hal tersebut sesuai dengan penelitian Kartini dkk (2010) yang menyatakan pengelolaan dapat diartikan sebagai proses, cara, perbuatan mengelola proses melakukan kegiatan tertentu dengan menggerakkan tenaga orang lain proses yang membantu merumuskan kebijaksanaan dan tujuan organisasi. Proses yang memberikan pengawasan dan pencapaian tujuan sebagai perangkat unsur yang secara teratur saling berkaitan sehingga membentuk suatu totalitas, susunan yang teratur.

Pada pengelolaan program Kampung Sayur Organik yang dilakukan oleh Kelompok Swadaya Masyarakat Kahuripan Sejahtera diperlukan perencanaan untuk mencapai tujuan yang diharapkan oleh Kelompok Swadaya Masyarakat Kahuripan Sejahtera yaitu sebagai payung Gerakan pemberdayaan masyarakat serta menjadi pusat pembelajaran masyarakat bidang pertanian dan kesehatan lingkungan Hal tersebut sesuai dengan teori Terry (2010) yang menyatakan Perencanaan (Planning) ialah penetapan pekerjaan yang harus dilaksanakan oleh kelompok untuk mencapai tujuan yang digariskan. Planning mencakup kegiatan pengambilan keputusan, karena termasuk dalam pemilihan alternatif-alternatif keputusan. Sangat diperlukan kemampuan untuk mengadakan visualisasi dan melihat ke depan guna merumuskan suatu pola dari himpunan tindakan untuk masa mendatang.

Perencanaan yang dilakukan oleh Kelompok Swadaya Masyarakat Kahuripan Sejahtera melibatkan Rumah Zakat dan warga Kampung Ngemplak Sutan dari awal perencanaan Program Kampung Sayur Organik dan kegiatan Kampung Sayur Organik meliputi kegiatan urban farming, pertemuan rutin, koperasi benih, dan bank sampah. Perecanaan program Kampung Sayur Organik dilakukan sejak tahun 2014. Perencanaan dilakukan di pertemuan rutin bertempat di rumah Bapak Mulyadi .

Dalam pengelolaan program Kampung Sayur Organik diperlukan adanya pengorganisasian yang dilakukan Kelompok Swadaya Masyarakat Kahuripan Sejahtera bersama Rumah Zakat pengorganisasian yang dilakukan oleh Kelompok Swadaya Masyarakat Kahuripan Sejahtera adalah pembagian tugas untuk kepengurusan Kelompok Swadaya Masyarakat Kahuripan Sejahtera, yang 
ditetapkan pada saat pertemuan rutin kelompok. Tujuan dari pembagian tugas oleh Kelompok Swadaya Masyarakat Kahuripan Sejahtera adalah agar dapat membagi tugas dengan tanggung jawab masing - masing sehingga memudahkan koordinasi anggota Kelompok Swadaya Masyarakat Kahuripan Sejahtera agar dapat menjalin Kerjasama dan bertanggung jawab. Hal tersebut sesuai dengan hasil penelitian Andini (2013) yang mengatakan bahwa pengorganisasian komunitas merupakan salah satu proses yang meemobilisasi komunitas untuk mencapai atau berbuat tindakan bersama demi kepentingan komunitas dan memberikan dampak bagi komunitasnya.

Tugas kepengurusan Kelompok Swadaya Masyarakat Kahuripan Sejahtera meliputi Ketua sebagai pemimpin serta menyetujui keputusan yang dilaksanakan dalam rapat antar anggota, Penasehat bertugas melakukan pengawasan dan penilaian . sekteratis yang membuat proposal pengajuan pelatihan dan mencatat di setiap kegiatan, , bendahara tugasnya merekap pengeluaran yang dibutuhkan, perlengkapan bertugas dalam mengatasi permasalahan alat sarana dan prasaranan di setiap kegiatan.

Pelaksanaan program Kampung Sayur Organik dilakukan melalui berbagai kegiatan yang merupakan bentuk implementasi dari program Kampung Sayur Organik. Bentuk kegiatan dari implementasi program Kampung Sayur Organik diantaranya yaitu kegiatan urban farming, pertemuan rutin, koperasi benih dan bank sampah yang dimana setiap kegiatan di tujukan kepada warga Kampung Ngemplak Sutan sekaligus anggota Kelompok Swadaya Masyarakat Kahuripan Sejahtera. Hal tersebut sesuai dengan teori Terry (2010) yang menyatakan pelaksanaan merupakan usaha menggerakkan anggota - anggota kelompok sedemikian rupa, hingga mereka berkeinginan dan berusaha untuk mencapai tujuan yang telah direncanakan bersama

.etiap kegiatan dari program Kampung Sayur Organik memiliki tempat dan waktu berbeda. Pada kegiatan urban farming dapat dilakukan di rumah warga masing - masing dan kapan saja karena kegiatan berupa pemanfaatan lahan pekarangan, kegiatan pertemuan rutin dilakukan hanya pada tanggal 20 setiap bulannya dan bertempat di rumah Bapak Mulyadi, kegiatan koperasi benih 
Ramajaya, et.al. Pemberdayaan Masyarakat Melalui Program Kampung Organik

bertempat di rumah Bapak Paryanto, kegiatan Bank Sampah dapat dilakukan kapan saja menyesuaikan dengan keadaan.

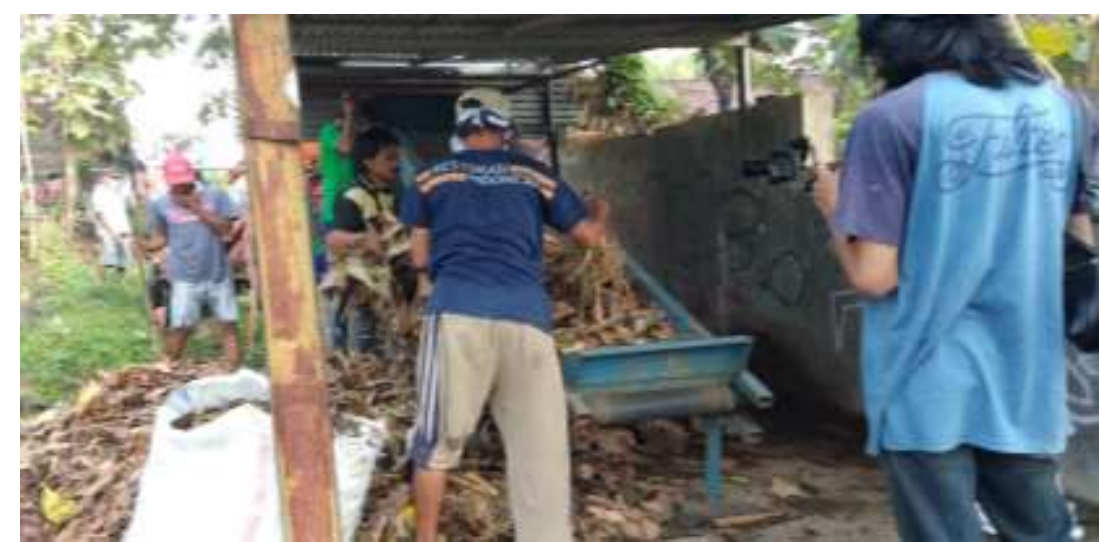

Gambar 2. Pelaksanaan kegiatan cacah sampah organik rutin Sumber: Dokumen Pribadi (2020)

Dalam program Kampung Sayur Organik terdapat pengawasan oleh Kelompok Swadaya Masyarakat Kahuripan Sejahtera yang dibantu bersama warga Kampung Ngemplak Sutan. Pengawasan program Kampung Sayur Organik berkaitan dengan pengawasan pelaksanaan kegiatan program. Dalam pengawasan yang dilakukan oleh Kelompok Swadaya Masyarakat Kahuripan Sejahtera, evaluasi tersebut meliputi pemecahan masalah - masalah yang terjadi dilapangan saat melakukan kegiatan program, pemberian saran dan masukan sekaligus pelaporan hasil kegiatan setiap bulannya yang dilakukan setiap bulan pada pertemuan rutin tanggal 20. Hal ini sesuai dengan penelitian Baihaqi (2016) Pengawasan merupakan salah satu fungsi manajemen yang turut mendorong tercapainya tujuan-tujuan yang telah ditetapkan. Tindakan atau kegiatan yang telah direncanakan dalam pelaksanaan perlu adanya suatu pengawasan

\section{Proses Pemberdayaan Masyarakat Kampung Ngemplak Sutan Melalui Program} Kampung Sayur Organik

Wrihatnolo dan Dwidjowijoto (2007) mengungkapkan bahwa pemberdayaan adalah sebuah "proses menjadi” bukan sebuah "proses instan". Sebagai proses, pemberdayaan mempunyai 3 tahapan, yaitu : penyadaran, peningkatan kapasitas dan pemberian daya. Penyadaran terhadap warga Kampung 
Ngemplak Sutan dilakukan oleh Rumah Zakat bersama Cita Sehat Foundation dan beberapa warga pionir perubahan. Penyadaran mulai dilakukan sejak tahun 2010 dann dilakukan di lingkungan Kampung Ngemplak Sutan melalui sosialisasi terkait PHBS dan kemudian mulai merambah kegiatan Urban Farming di tahun 2013. Kegiatan Penyadaran dilakukan melalui media Forum yang ada di Kampung Ngemplak Sutan seperti pertemuan rutin RT/RW, ibu - ibu PKK, dan arisan. Usaha / kegiatan yang dilakukan Rumah Zakat agar warga Kampung Ngemplak Sutan percaya pada program Agar warga percaya terhadap program Kampung Sayur ORganik materi yang diberikan dalam proses penyadaran terhadap waga Kampung Ngemplak Sutan berupa materi tentang Urban Farming meliputi tentang bercocok tanam dari olah tanah hingga panen, pengelolaan limbah rumah tangga, dan perilaku hidup bersih dan sehat (PHBS). Selain itu juga diajak untuk praktek langsung sehingga lebih mudah menyerap informasi. Hal tersebut sesuai dengan teori Wrihatnolo dan Dwidjowijoto (2007) yang menyatakan pada tahap pertama, masyarakat diberi pengetahuan yang bersifat kognitif, belief dan healing. Prinsip dasarnya adalah membuat target mengerti bahwa mereka perlu diberdayakan dan proses pemberdayaan tersebut dimulai dari dalam diri mereka (bukan dari orang luar).

Pengkapasitasan melalui program Kampung Sayur Organik berupa pengkapasitasan manusia, lingkungan, usaha , dan kelembagaan. Pengkapasitasan manusia tersebut berupa pelatihan terkait Urban Farming cara memanfaatkan lahan pekarangan dengan bercocok tanam dan berternak, cara pengolahan hasil panen sayuran, dan cara manjemen pembukuan. Pada Pengkapasitasan lingkungan dilakukan melalui cara pengelolaan lingkungan dengan baik melalui kegiatan Urban Farming serta PHBS. Pada pengkapasitasan kelembagaan adalah dengan membentuk sebuah wadah yaitu KSM Kahuripan Sejahtera. Pada pengkapasitasan usahan meliputi adanya pelatihan pengelolaan hasil panen dan pendirian Bank Sampah Pada proses pengkapasitasan melibatkan beberapa pemangku kepentingan diantaranya yaitu (1) OISCA Karanganyar. (2) Dinas pertanian kota Surakarta (3) Dinas ketahanan pangan kota Surakarta (4) UNS Lokasi pelatihan yang diikuti oleh warga Kampung Ngemplak Sutan disesuaikan dengan lokasi kegiatan dan 
Ramajaya, et.al. Pemberdayaan Masyarakat Melalui Program Kampung Organik

ditentukan oleh penyelenggara sehinngga pelatihan terkadang dilakukan di Kampung Ngemplak Sutan dan terkadang di luar lokasi sesuai dengan ketentuan penyelenggara. Hal tersebut sesuai dengan pernyataan Widjajanti (2011) menjelaskan bahwa peran modal manusia menjadi landasan mengembangkan pemberdayaan dan menjadi mediasi peningkatkan keberdayaan masyarakat dari modal fisik. Oleh karena itu, sharing pengetahuan merupakan syarat untuk dapat meningkatkan kreativitas dan inovasi. Masyarakat akan lebih optimal dalam pengembangan pemberdayaan apabila didukung proses peningkatan kualitas manusianya.

Wrihatnolo dan Dwidjowijoto (2007) menjelaskan bahwa tahap ketiga adalah pemberian daya itu sendiri atau empowerment. Pada tahap ini masyarakat diberi daya, kekuasaan, otoritas atau peluang. Masyarakat diberi kewenangan dalam mengidentifikasi masalah dan strategi yang tepat untuk mengatasi masalah tersebut. Masyarakat juga diberi ukuran-ukuran yang dapat digunakan untuk mengukur keberhasilan. Rumah Zakat selaku organisasi yang melalui relawannya memberi pendampingan memberikan wewenang kepada KSM Kahuripan sejahtera untuk mengelola program Kampung Sayur Organik bersama warga Kampung Ngemplak Sutan berupa kebebasan penuh dalam mengelola program mulai dari pengambilan keputusan, pengawasan dan evaluasi, serta bebas melakukan inovasi sendiri. Sehingga Peran dari KSM Kahuripan Sejahtera selain sebagai pengelola program Kampung Sayur Organik juga berperan sebagai kelompok yang bertugas mengedukasi dan membina warga Kampung Ngemplak Sutan terkait Urban Farming.

Pemberian daya dilakukan tidak secara formal, relawan dari Rumah Zakat sudah tidak lagi membina warga pada tahun 2015, Wewenang diberikan kepada KSM Kahuripan Sejahtera dan warga Kampung Ngemplak Sutan karena Rumah Zakat percaya bahwa KSM Kahuripan Sejahtera sudah memiliki kapasitas dan kemampuan dalam mengelola dan memberdayakan serta bekerja sama dengan warga Kampung Ngemplak Sutan dalam mengelola program Kampung Sayur Organik dengan baik. Wewenang juga diberikan agar anggota KSM Kahuripan Sejahtera dan warga Kampung Ngemplak Sutan dapat berinovasi, berkreasi, 
menyalurkan ide - ide mereka dan mengeksplor kemampuang mereka sendiri sehingga memajukan program Kampung Sayur Organik.

\section{SIMPULAN}

Pada proses pemberdayaan program Kampung Sayur Organik di Kampung Ngemplak Sutan yang dilakukan oleh Rumah Zakat telah menerapkan prinsip pemberdayaan yaitu prinsip membangun, merubah kukltur masyarakat, dan sistem. Pengelolaan program Kampung Sayur Organik oleh KSM Kahuripan Sejahtera di Kampung Ngemplak Sutan dilakukan melalui perencanaan, pengorganisasian, pelaksanaan, dan pengawasan. Kegiatan pada program Kampung Sayur Organik yaitu kegiatan Urban Farming, Pertemuan Rutin, Koperasi Benih, dan Bank Sampah. Proses peberdayaan warga Kampung Ngemplak Sutan melalui program Kampung Sayur Organik melalui tiga tahapan yaitu tahap penyadaran, tahap pengkapasitasan, dan tahap pemberian daya

KSM Kahuripan Sejahtera perlu memaksimalkan dan memanfaatkan hasil panen tanaman sayuran, buah, dan juga ternak warga dengan cara meningkatkan skala usaha yang dari perindividu menjadi berkelompok KSM Kahuripan Sejahtera perlu mencari anggota kandidat yang memiliki kapasitas dalam bidang teknologi informasi untuk melakukan kegiatan promosi / mengiklankan Kampung Sayur Organik melalui jejaring sosial agar Kampung Sayur Organik lebih dikenal masyarakat luas

\section{UCAPAN TERIMA KASIH}

Ucapan terima kasih diberikan kepada Dosen dan Tenaga Pendidik di lingkungan Fakultas Pertanian atas bimbingan dan dukungannya serta pihak LPPM Universitas Pembangunan Nasional "Veteran" Yogyakarta atas bantuan yang berupa pendanaan dalam penelitian dan penulisan karya ilmiah ini.

\section{DAFTAR PUSTAKA}

Baihaqi. (2016). Pengawasan Sebagai Fungsi Manajemen Perpustakaan Dan Hubungan Dengan Disiplin Pustakawan. Libria 8 (1), 129-142. 
Ramajaya, et.al. Pemberdayaan Masyarakat Melalui Program Kampung Organik

Dwijdowijoto, N. Riant dan Wrihatnolo R. Randy. (2007). Manajemen Pemberdayaan. Jakarta: Elex Media Komputindo.

Hakim Luqmanul. (2017). Partisipasi Masyarakat Dalam Pembangunan Desa Sukamerta Kecamatan Rawamerta Kabupaten Karawang. Jurnal Politikom Indonesiana, 2 (2), 43-53

Andini Nurulitha. (2013). Pengorganisasian Komunitas dalam Pengembangan Agrowisata di Desa Wisata Studi Kasus: Desa Wisata Kembangaruk, Kabupaten Sleman. Jurnal Perencanaan Wilayah dan Kota, 24 (3), 173 188.

Kartini, A.R., Mustakim, \& Liwaul. (2018). Sistem Pengelolaan Pajak Bumi Dan Bangunan Dalam Meningkatkan Pendapatan Asli Daerah Pada Badan Pengelola Pajak Dan Retribusi Daerah Kota Kendari. Jurnal Administrasi Bisnis, 3 (2), 302-311.

Sugiyono. (2017). Metode Penelitian Kuantitatif, Kualitatif, Dan $R \&$ D. Bandung : Alfabeta.

Sulaiman, Endang Sutisna. (2012). Pemberdayaan Masyarakat di Bidang Kesehatan: Teori dan Implementasi. Yogyakarta: Gadjah Mada University Press.

Terry, R, George. (2010). Prinsip - prinsip Manajemen. Jakarta: Bumi Aksara

Widjajanti Kesi. (2011). Model Pemberdayaan Masyarakat. Jurnal Ekonomi Pembangunan, 12 (1), 15-27. 